\title{
PROPOSAL
}

\section{KORELASI KETERAMPILAN MEMAHAMI TEKS ANEKDOT DENGAN KETERAMPILAN MENULIS TEKS ANEKDOT SISWA KELAS X SMK NEGERI 3 PARIAMAN}

Diajukan untuk memenuhi tugas perkuliahan Metode Penelitian Pembelajaran Bahasa Indonesia yang dibina oleh Prof. Dr. Syahrul R, M. Pd.

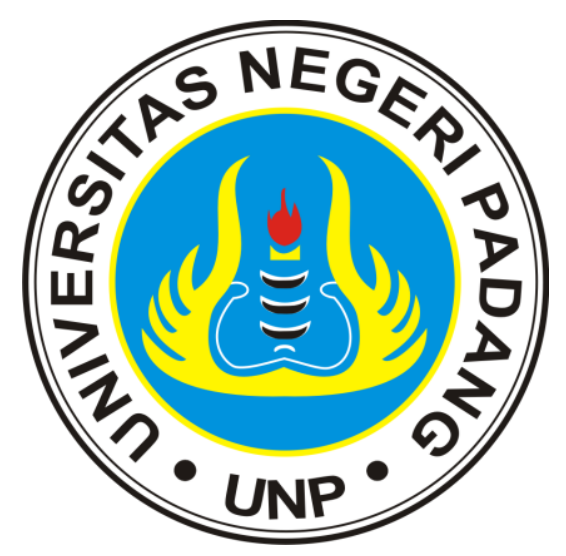

RESTI FAUZI

19016043

PROGRAM STUDI PENDIDIKAN BAHASA INDONESIA

JURUSAN BAHASA DAN SASTRA INDONESIA DAN DAERAH

FAKULTAS BAHASA DAN SENI

UNIVERSITAS NEGERI PADANG 


\section{KATA PENGANTAR}

Puji dan Syukur kami panjatkan ke Hadirat Tuhan Yang Maha Esa, karena berkat limpahan Rahmat dan Karunia-nya sehingga kami dapat menyusun proposal ini dengan baik dan benar, serta tepat pada waktunya. Dalam proposal ini kami akan membahas mengenai "Korelasi Keterampilan Memahami Teks Anekdot dengan Keterampilan Menulis Teks Anekdot Siswa Kelas X SMK Negeri 3 Pariaman".

Proposal ini telah dibuat dengan bantuan dari berbagai pihak untuk membantu menyelesaikan tantangan dan hambatan selama mengerjakan proposal ini. Oleh karena itu, kami mengucapkan terima kasih yang sebesar-besarnya kepada semua pihak yang telah membantu dalam penyusunan proposal ini.

Kami menyadari bahwa masih banyak kekurangan yang mendasar pada proposal ini. Oleh karena itu kami meminta pembaca untuk memberikan saran serta kritik yang dapat membangun kami. Kritik konstruktif dari pembaca sangat kami harapkan untuk penyempurnaan proposal selanjutnya.

Pariaman, November 2021

Penulis 


\section{DAFTAR ISI}

HALAMAN

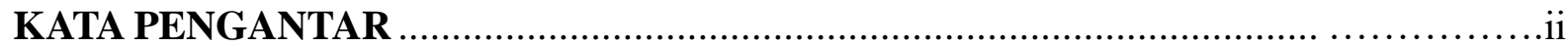

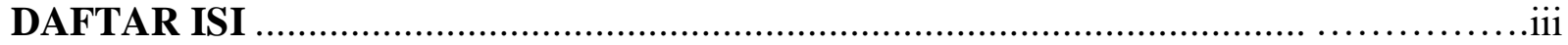

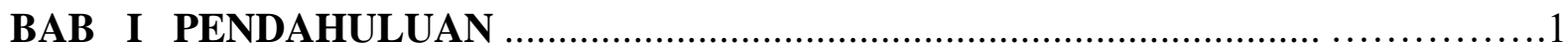

A. Latar Belakang Masalah ................................................................

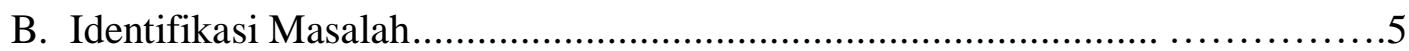

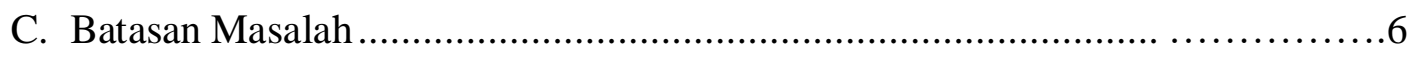

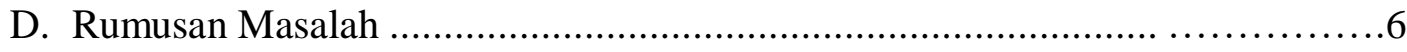

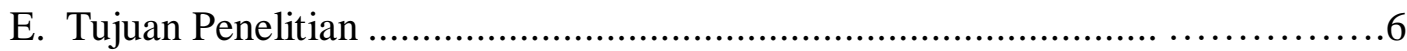

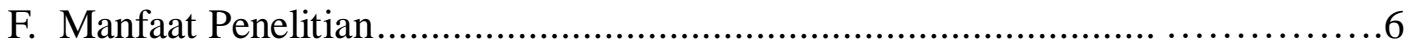

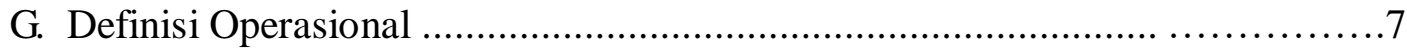

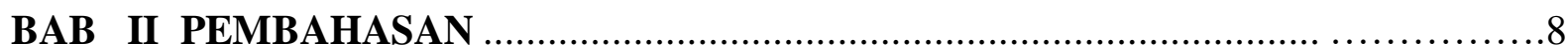

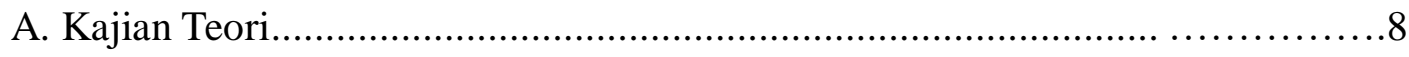

1. Keterampilan Menulis Teks Anekdot................................................

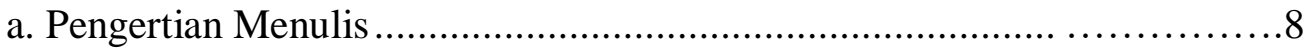

b. Pengertian Teks Anekdot .........................................................

c. Struktur Teks Anekdot ….................................................................

d. Kaidah Kebahasaan Teks Anekdot ....................................................10

e. Langkah-langkah Menulis Teks Anekdot ............................................11

f. Indikator Penilaian Keterampilan Menulis Teks Anekdot ....................12

2. Keterampilan Memahami Teks Anekdot................................................15

a. Pengertian Keterampilan Memahami Teks Anekdot ............................15 
b. Tujuan Keterampilan Memahami Teks Anekdot ............................16

c. Indikator Keterampilan Memahami Teks Anekdot .........................16

3. Korelasi Keterampilan Memahami Teks Anekdot dengan Keterampilan Menulis Teks Anekdot .................................................................... 17

B. Penelitian yang Relevan............................................................. 18

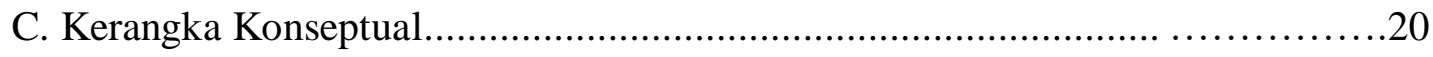

D. Hipotesis Penelitian ............................................................ 21

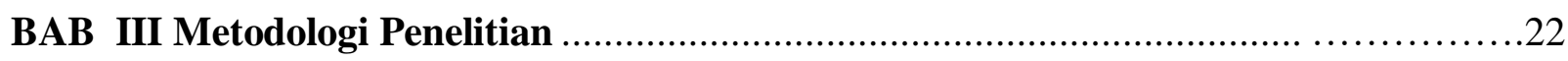

A. Jenis Penelitian.................................................................... 22

B. Populasi dan Sampel ...............................................................22

C. Variabel dan Data ........................................................................2 23

D. Instrumen Penelitian .......................................................................2 23

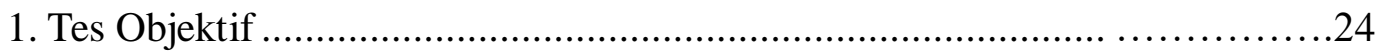

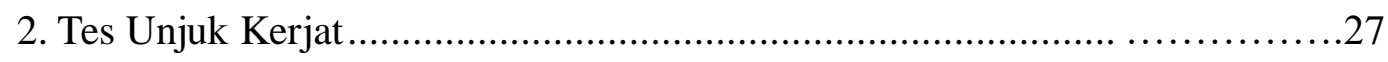

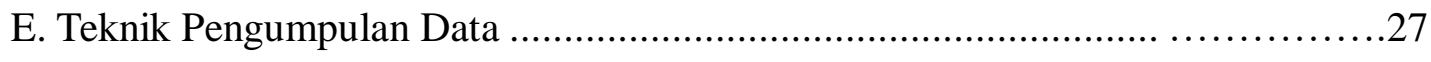

F. Uji Persyaratan Analisis Data .......................................................28

G. Teknik Penganalisisan Data .......................................................28

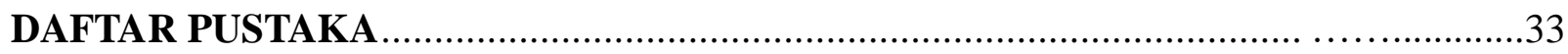




\section{BAB I \\ PENDAHULUAN}

\section{A. Latar Belakang Masalah}

Dengan kemajuan ilmu komunikasi yang menabjubkan, keterampilan menulis menjadi semakin penting dalam kehidupan akademik dan kehidupan nyata (Sayed, 2010). Gani (dalam Apriyenti et al., 2019) menyatakan bahwa menulis merupakan sebuah upaya untuk mewujudkan segala sesuatu yang dialami, dirasakan, dan dipikirkan ke dalam lambang-lambang atau simbol-simbol bahasa tulisan bahasa. Penelitian tentang menulis telah dilakukan (Cole \& Feng, 2015) dari China yang mengungkapkan siswa sulit mengidentifikasi keterampilan menulis dari pada mendengarkan dan membaca. Hal tersebut menunjukan bahwa keterampilan menulis sulit dikuasai siswa. Hasil penelitian tersebut menunjukkan bahwa waktu yang digunakan untuk menulis lebih sedikit dibandingkan dengan waktu untuk berbicara, membaca, dan menyimak. Keterampilan menulis bukan hanya pilihan bagi kaum muda tetapi sebuah keharusan (Graham dan Perin, 2007). Bagi siswa, keterampilan menulis adalah salah satu prediktor terbaik untuk keberhasilan akademik (Geiser \& Studley, 2010). Kegiatan menulis masih kurang diminati, sehingga menduduki peringkat terendah. Supriadin (2016:2) mengatakan bahwa menulis berhubungan dengan kemampuan seseorang menuangkan ide dan gagasannya dalam sebuah karya. Selanjutnya, Setyawan et al (dalam Frecelya, 2019) menyatakan bahwa keterampilan menulis akan sangat dipengaruhi oleh perbendaharaan kosakata karena untuk mampu menulis diperlukan pula kemampuan untuk memilih kosakata yang tepat untuk mengekspresikan pikiran dan perasaan. Hasil penelitian Syaidati (dalam Widia, 2020: 196) menunjukkan bahwa kemampuan siswa dalam menulis masih rendah dan masih perlu dilakukan perbaikan. Pembelajaran menulis harus dilaksanakan dengan menyeimbangkan antara proses dan produk yang dihasilkan berupa hasil tulisan karena menulis merupakan suatu kegiatan yang produktif dan ekspresif.

Pudjidarto (dalam Ghazali, 2020: 11), menyatakan dari hasil ulangan harian di sekolah menunjukan bahwa menulis merupakan kegiatan yang tidak diminati siswa karena siswa kesulitan untuk menuangkan ide. Siswa yang tidak terampil menulis akan sulit menuangkan dan mengembangkan idenya. Meskipun siswa tersebut memiliki banyak ide dalam pemikirannya, ide 
tersebut tidak bisa disampaikan secara rinci. Siswa juga harus menguasai pembelajaran bahasa Indonesia di antaranya, kaidah-kaidah dalam menulis, kosakata, dan Ejaan Bahasa Indonesia (EBI) untuk terampil menulis. Permasalahan ini menambah alasan pentingnya pembelajaran menulis bagi siswa. Dalam keterampilan menulis juga dibutuhkan cara berpikir teratur yang menuntut latihan secara berkesinambungan dan terpola secara sistematis. Keterampilan menulis dapat mengarahkan siswa agar mampu menyampaikan ide dan gagasan untuk berbagai tujuan secara tertulis. Menurut Aidawati (dalam Dalman, 2016) menulis merupakan tanggapan terhadap sesuatu dengan menggunakan media tulisan dalam pembelajaran di sekolah, menulis dapat dimanfaatkan siswa untuk mencatat, melaporkan, serta memperluas wawasan dan pengetahuan. Permasalahan keterampilan menulis juga ditemukan di kalangan masyarakat umum dan dunia pendidikan nasional. Rendahnya kemampuan menulis diakibatkan oleh beberapa faktor. Secara umum menulis cenderung dianggap sulit oleh siswa, karena menulis menuntut perhatian, pemahaman, dan keseriusan siswa untuk menggali potensi yang ada dalam dirinya. Siswa harus lebih aktif lagi sehingga tulisan yang dihasilkan akan bagus. Melalui kegiatan menulis siswa dapat mengungkapkan gagasan dan pikiran dalam suatu kerangka berpikir yang logis dan sistematis. Keterampilan menulis tidak akan datang secara otomatis, tetapi harus melalui praktik dan banyak berlatih dalam menulis. keterampilan menulis dibentuk dari beberapa keterampilan berbahasa (keterampilan menyimak, keterampilan berbicara, dan keterampilan membaca). Britton (dalam Marisa, 2018) menyatakan bahwa keberhasilan menulis dipengaruhi oleh pemahaman penulis terhadap pembaca tulisannya. Kemampuan ini memungkinkan kita sebagai penulis untuk memilih informasi serta cara penyajian yang sesuai. Selanjutnya dalam penelitian Haniah (dalam Ghazali, 2020: 11) mengungkapkan bahwa di dunia perguruan tinggi, banyak insan akademis terutama mahasiswa yang kurang membudayakan kegiatan menulis. Ada dua faktor yang menyebabkan hal tersebut. Pertama, rendahnya minat baca di kalangan akademisi. Kedua, Rendahnya kemampuan berbahasa Indonesia yang baik dan benar. Kurangnya keterampilan membaca dan menulis mahasiswa di perguruan tinggi juga akan berdampak kepada keterampilan beretorika. Bahasa dapat digunakan sebagai alat komunikasi, melalui bahasa seseorang dapat berkomunikasi,berinteraksi dengan orang lain, mengekspresikan perasaan, dan sebagainya. Beberapa peneliti telah menyelidiki faktor lainnya yang menyebabkan keterampilan menulis sulit dikuasai, misalnya, penelitian di Iran (Safa, 2018), menunjukkan bahwa faktor yang 
memengaruhi keterampilan menulis adalah sikap, motivasi, pengetahuan linguistik, dan kosakata.

Kenyataan di lapangan menunjukkan bahwa dalam keterampilan menulis, siswa masih banyak mengalami kesulitan. Priyatna (dalam Rahmawita, 2019), mengatakan bahwa beberapa penyebab rendahnya keterampilan menulis siswa yaitu faktor kesulitan siswa dalam mengembangkan ide, gagasan, kurangnya minat siswa dalam pembelajaran menulis karena adanya anggapan menulis adalah kegiatan yang membosankan dan sangat sulit. Selain itu, kurangnya waktu yang sudah ditentukan dalam pembelajaran mengarang menyebabkan siswa tidak dapat menyelesaikan hasil karangan secara lengkap.Begitu pula dengan menulis teks anekdot. Maryanto et al (2014:111) mengemukakan bahwa anekdot termasuk dalam jenis teks cerita. Menurut Sari (2016: 3) anekdot digunakan untuk memakai kata joke bahasa Inggris dalam spoof text yang diartikan suatu narasi atau percakapan yang lucu. Isi cerita anekdot dapat juga mengungkapkan pesan terhadap fenomena sosial yang terjadi di lingkungan penulis baik berupa pujian, solusi, maupun kritik secara tidak langsung. Teks anekdot ini merupakan cerita lucu yang bertujuan untuk menyampaikan kritikan terhadap tokoh yang diceritakan. Wardani (2017:46) menyatakan bahwa teks anekdot merupakan sebuah cerita singkat, namun lucu dan isinya berupa sindiran. Tokoh yang diceritakan tersebut dapat berupa tokoh terkenal atau bersifat faktual. Menulis teks anekdot tercantum dalam KI 4 dan KD 4.6. Pada KI 4, siswa mengolah, menalar, dan menyaji dalam ranah konkret dan ranah abstrak terkait dengan pengembangan dari yang dipelajarinya di sekolah secara mandiri, dan mampu menggunakan metoda sesuai kaidah keilmuan. Pada KD 4.6 siswa menciptakan kembali teks anekdot dengan memerhatikan struktur dan kebahasaan. Menurut Darmawati (2016:100) anekdot memiliki struktur yang membedakannya dengan jenis narasi lainnya. Struktur anekdot terbagi atas lima, yaitu abstrak, orientasi, krisis, reaksi, dan koda. Abstrak berada di paragraf awal anekdot. Hal tersebut sejalan dengan pemaparan Kosasih (2013:15) menyatakan bahwa anekdot tidak semata-mata menyajikan hal-hal yang lucu, guyonan, ataupun humor akan tetapi terdapat pula tujuan lain di balik cerita tersebut, yaitu berupa pesan yang diharapkan bisa memberikan pelajaran pada khalayak. Selain itu, penulis tidak hanya mampu menyampaikan sindiran atau kritikan dalam tulisannya, tetapi juga harus mampu menciptakan nilai humor agar dapat menarik perhatian pembacanya. Siswa yang belum mampu menulis teks anekdot dengan baik disebabkan karena 
siswa kurang memahami mengenai struktur teks, kalimat penjelas dan terkadang masih bingung dalam menentukan tema dan mengembangkan ide yang akan ditulis dalam teks anekdot. Selain itu, siswa juga sering merasa jenuh apabila guru memberi tugas menulis atau mengarang. Hal tersebut didukung oleh pernyataan T. Hedge (dalam Ghazali, 2013:293) yang mengemukakan bahwa jika dibandingkan dengan kegiatan berbicara, kegiatan menulis harus memenuhi beberapa syarat yang tidak berlaku bagi kegiatan berbicara agar penulisan itu bisa efektif, yaitu: pengorganisasian yang ketat pada pengembangan ide dan informasi, tingkat akurasi yang tinggi agar tidak ada keraguan makna, penggunaan sarana-sarana tatabahasa yang kompleks agar bisa membuat pembaca terfokus pada penekanan-penekanan yang diberikan penulis, dan pemilihan kosakata, pola tatabahasa, dan struktur kalimat secara saksama agar bisa menciptakan gaya yang sesuai bagi tema dan bagi pembacanya nanti. Menurut penelitian yang dilakukan Maulana (dalam Rahmawita, 2019) pada umumnya menulis dianggap sebagai suatu keterampilan berbahasa yang sangat sulit dan dijadikan beban oleh siswa. Kesulitan ini disebabkan oleh faktor psikologis dan metodologis. Secara psikologis, kebanyakan siswa menganggap bahwa kegiatan menulis sebagai beban karena merasa kurang mampu menggunakan bahasa Indonesia dengan baik dan benar. Secara metodologis, guru umumnya kurang bervariasi dalam memilih metode yang digunakan. Hal itu tidaklah berlebihan karena menulis merupakan sebuah kegiatan yang kompleks. Kendala lain adalah kurang mampunya siswa menggunakan bahasa Indonesia dengan baik dan benar sesuai dengan kaidah ejaan yang disempurnakan.

Membaca merupakan salah satu keterampilan berbahasa yang memiliki peranan penting untuk memperoleh keterampilan-keterampilan berbahasa lainnya khususnya keterampilan menulis. Namun, keterampilan membaca anak bangsa saat ini tergolong rendah. Sesuai laporan Bank Dunia no 16369-IND dan studi IEA (International Association for the Evolution of Education Achievermen) di Asia Timur, menunjukkan bahwa minat terendah membaca anakanak dipegang oleh negara Indonesia. Kajian PIRLS (Progress in International Reading Literacy Study) yaitu studi internasional dalam bidang membaca pada anak-anak di seluruh dunia yang disponsori oleh IEA ini menunjukkan bahwa rata-rata anak Indonesia berada pada urutan keempat dari bawah dari 45 negara di dunia. Hal ini membuktikan bahwa kemampuan membaca dan menulis bangsa Indonesia masih rendah (Fitrianita dalam Wardani dkk, 2017: 426). 
Salah satu keterampilan yang harus dimiliki siswa sebagai langkah untuk meningkatkan keterampilan menulis teks anekdot adalah membaca pemahaman. Membaca pemahaman merupakan suatu kegiatan membaca yang bertujuan untuk memahami isi yang terkandung di dalam bacaan. Jika seseorang telah dapat memahami isi teks yang dibacanya, akan lebih mudah untuk menuangkan ide yang ada dalam pikirannya ke dalam bentuk tulisan. Agustina (2008:15) mengatakan, bahwa membaca pemahaman adalah membaca yang dilakukan tanpa mengeluarkan bunyi atau suara. Membaca ini tidak menuntut pembacanya untuk membunyikan atau mengoralkan bacaannya, tetapi hanya menggunakan mata untuk melihat serta pikiran untuk memahainya. Mangen et al (2013), dalam penelitiannya membuktikan bahwa siswa yang memiliki pemahaman yang baik akan mendapat skor yang jauh lebih baik daripada siswa yang tidak memiliki pemahaman sama sekali. Menurut Anderson dan Krathwohl (2010), pemahaman adalah proses menafsirkan, mencontohkan, mengklasifikasikan, merangkum, menginferensi, membandingkan, dan menjelaskan. Sementara itu, menurut Bloom (dalam Sagala, 2011:157), pemahaman (comprehension) mengacu pada kemampuan untuk mengerti dan memahami sesuatu setelah sesuatu itu terlebih dahulu diketahui atau diingat dan memaknai arti dari materi yang dipelajari. Berdasarkan permasalahan di atas, peneliti menggajukan judul penelitian "Korelasi Keterampilan Memahami Teks Anekdot dengan Keterampilan Menulis Teks Anekdot Siswa Kelas X SMK Negeri 3 Pariaman”.

\section{B. Identifikasi Masalah}

Berdasarkan uraian yang telah dikemukakan dalam latar belakang masalah di atas, maka identifikasi masalah dalam penelitian ini adalah sebagai berikut. Pertama, dalam memahami, siswa kurang mampu memaknai bacaan yang dibacanya karena sulit berkonsentrasi. Kedua, dalam menulis, kurangnya perhatian siswa dalam pemilihan kata dan pemakaian tanda baca. Ketiga, siswa kesulitan dalam mengembangkan ide, gagasan, kurangnya minat siswa dalam pembelajaran menulis karena adanya anggapan menulis adalah kegiatan yang membosankan dan sangat sulit. Keempat, siswa kurang memahami mengenai struktur teks, kalimat penjelas dan terkadang masih bingung dalam menentukan tema dan mengembangkan ide yang akan ditulis dalam teks anekdot. Kelima, siswa menganggap bahwa kegiatan menulis sebagai beban karena merasa kurang mampu menggunakan bahasa Indonesia dengan baik dan benar. Keenam, guru 
umumnya kurang bervariasi dalam memilih metode yang digunakan. Ketujuh, siswa kurang mampunya menggunakan bahasa Indonesia dengan baik dan benar sesuai dengan kaidah ejaan yang disempurnakan.

\section{Batasan Masalah}

Berdasarkan identifikasi masalah tersebut, permasalahan penelitian ini dibatasi pada korelasi keterampilan memahami teks anekdot dengan keterampilan menulis teks anekdot siswa kelas X SMK Negeri 3 Pariaman.

\section{Rumusan Masalah}

Rumusan masalah dalam penelitian ini adalah sebagai berikut. Pertama, bagaimanakah keterampilan memahami teks anekdot siswa kelas X SMK Negeri 3 Padang Pariaman. Kedua, bagaimanakah keterampilan menulis teks anekdot siswa kelas X SMK Negeri 3 Pariaman. Ketiga, apakah terdapat korelasi antara keterampilan memahami teks anekdot dengan keterampilan menulis teks anekdot siswa kelas X SMK Negeri 3 Pariaman.

\section{E. Tujuan Penelitian}

Penelitian ini memiliki tiga tujuan. Pertama, mendeskripsikan keterampilan memahami teks anekdot siswa kelas X SMK Negeri 3 Pariaman. Kedua, mendeskripsikan keterampilan menulis teks anekdot siswa kelas X SMK Negeri 3 Pariaman. Ketiga, menganalisis korelasi antara keterampilan memahami teks anekdot dengan keterampilan menulis teks anekdot siswa kelas X SMK Negeri 3 Pariaman.

\section{F. Manfaat Penelitian}

Penelitian ini memiliki dua manfaat, yaitu menfaat teoretis dan manfaat praktis. Secara teoretis, penelitian ini diharapkan bermanfaat untuk menambah dan memperkaya teori ilmu pengetahuan dalam bidang menulis teks anekdot. Secara praktis, hasil penelitian ini diharapkan dapat memberikan manfaat kepada pihak-pihak berikut. Pertama, bagi guru bidang studi bahasa Indonesia kelas X SMK Negeri 3 Pariaman, yaitu bahan referensi untuk meningkatkan pembelajaran keterampilan menulis teks anekdot. Kedua, bagi siswa kelas X SMK Negeri 3 
Pariaman, yaitu untuk menumbuhkan minat baca dan meningkatkan keterampilan menulis siswa, khususnya menulis teks anekdot. Ketiga, bagi peneliti lain, sebagai bahan rujukan dan perbandingan untuk penelitian lebih lanjut.

\section{G. Definisi Operasional}

Bagian definisi operasional ditulis untuk menghindari kesalahan penafsiran terhadap pembaca. Ketiga istilah dimakasud sebagai berikut.

\section{Korelasi}

Korelasi adalah hubungan timbale balik atau sebab akibat antara dua hal. Korelasi juga dimaksudkan dalam proposal ini berkaitan antara keterampilan memahami teks anekdot dan keterampilan menulis teks anekdot.

\section{Keteramilan Memahami Teks Anekdot}

Keterampilan memahami teks anekdot yang dimaksud dalam proposal ini adalah hasil tes keterampilan siswa kelas X SMK Negeri 3 Pariaman dalam memahami teks anekdot yang dibaca.

\section{Keterampilan Menulis Teks Anekdot}

Keterampilan menulis teks anekdot yang dimaksud dalam proposal ini adalah hasil tes unjuk kerja berupa tes menulis teks anekdot. Siswa diharapkan mampu menulis teks anekdot dengan tiga indikator. Pertama,membuat struktur teks anekdot yaitu abstrak, orientasi, krisis, reaksi, dan koda. Kedua, isi teks anekdot harus relevan dengan topic, lengkap, dan subtantif. Ketiga, terdapat penggunaan unsure kebahasaan teks anekdot. 


\section{BAB II \\ KAJIAN PUSTAKA}

\section{A. Kajian Teori}

Berdasarkan permasalahan penelitian, terdapat tiga teori yang akan diuraikan pada kajian teori ini. Pertama, keterampilan memahami teks anekdot. Kedua, keterampilan menulis teks anekdot. Ketiga, korelasi keterampilan memahami teks anekdot dengan keterampilan menulis teks ankedot.

\section{Keterampilan Menulis Teks Anekdot}

Teori yang akan diuraikan dalam keterampilan menulis teks anekdot, yaitu (a) pengertian menulis, (b) pengertian teks anekdot, (c) struktur anekdot, (d) kaidah kebahasaan teks anekdot, (e) langkah-langkah menulis teks anekdot, dan (f) indikator penilaian keterampilan menulis teks anekdot.

\section{a. Pengertian Menulis}

Menurut Gani (1999:11), menulis merupakan suatu kegiatan untuk memproduksi sebuah tulisan berdasarkan gagasan yang ada dalam pikiran penulisnya. Segala sesuatu yang ditulis membutuhkan pembaca sehingga setiap hal yang ditulis harus mampu dipahami oleh pembaca. Tarigan (2009:22) menjelaskan bahwa menulis adalah menurunkan atau melukiskan lambang-lambang grafik yang menggambarkan suatu bahasa yang dipahami oleh seseorang sehingga orang lain dapat membaca lambanglambang grafik tersebut jika mereka memahami bahasa dan gambar grafik itu.

Menulis pada dasarnya adalah kegiatan mengolah pikiran dan mengkomunikasikan hasil pemikiran dalam bentuk tulisan atau karangan. Semi (2007: 14), menyatakan bahwa menulis merupakan suatu proses kreatif memindahkan gagasan ke dalam lambang-lambang tulisan. Sedangkan Dalman (2012:1) berpendapat bahwa menulis berarti mengorganisasikan gagasan secara sistematis dan mengungkapkannya secara tersurat, dengan kata lain menulis dapat berarti melukiskan lambang-lambang grafis yang menggambarkan suatu bahasa yang dipahami oleh seseorang. 
Pateda (1989: 100) mengatakan bahwa menulis adalah pengalihan bahasa lisan ke dalam bentuk tertulis. Tarigan (1994:21) mengemukakan bahwa menulis adalah menurunkan atau menuliskan lambang-lambang grafik yang menggambarkan suatu bahasa yang dipahami oleh seseorang, sehingga orang lain dapat membaca lambanglambang grafik tersebut kalau mereka memahami bahasa dan gambaran grafik itu.

Berdasarkan definisi tersebut, dapat disimpulkan bahwa menulis merupakan salah satu alat komunikasi secara tidak langsung untuk menuangkan ide, pandangan, dan perasaan. Melalui menulis, seseorang dapat menyampaikan ide, pandangan dan perasaannya untuk dipahami oleh pembaca.

\section{b. Pengertian Teks Anekdot}

Teks dapat diartikan sebagai bentuk tulisan yang merupakan satu kesatuan bahasa yang lengkap. Sejalan dengan pendapat Wahyudi (dalam Aieny, 2020: 128) bahwa teks merupakan ungkapan pikiran manusia yang lengkap yang di dalamnya memiliki situasi dan konteks .Sejalan dengan pedapat Zainurrahman (2013: 128) mengungkapkan bahwa teks merupakan seperangkat unit bahasa baik lisan maupun tulisan, dengan ukuran tertentu dan makna tertentu, serta tujuan tertentu. teks bersifat sistematis dan memiliki struktur teratur, dengan elemen-elemen yang jika terjadi perubahan pada salah satu elemen maka akan berdampak sistematik. Teks bisa berupa kata, kalimat, paragraf atau wacana yang memiliki karakteristik tertentu yang secara konvesional diterima, Secara kognitif dipahami, yang kemudian karakteristik teks itu sendiri disebut tekstur.

Anekdot menurut Suherli, Suryaman, Septiaji dan Istiqomah (dalam Burohman, 2020) merupakan cerita singkat, lucu, dan mengesankan yang menceritakan tentang orang penting (tokoh masyarakat) digunakan untuk menyampaikan kritik, tetapi tidak dengan cara kasar dan menyakiti. Lalu menurut Prahasta (dalam Burohman, 2020) anekdot ialah tulisan singkat yang lucu, sederhana, menarik dan mengesankan yang bersifat mengeritik. Sejalan dengan pendapat di atas, Kosasih (2013) menyatakan teks anekdot yakni sebuah cerita lucu atau menggelitik yang bertujuan memberikan suatu pelajaran tertentu dan biasanya kisah dalam anekdot melibatkan tokoh tertentu yang bersifat faktual ataupun terkenal. 
Selain itu teks anekdot juga dapat berisi peristiwa yang membuat jengkel atau peristiwa yang dianggap konyol bagi orang yang mengalaminya. Pengertian lain yaitu teks anekdot tidak harus mengenai orang penting dan tidak harus kejadian yang sebenarnya (Burohman, 2020).

Wardani (2017:46) menyatakan bahwa teks anekdot merupakan sebuah cerita singkat, namun lucu dan isinya berupa sindiran.Tokoh yang diceritakan tersebut dapat berupa tokoh terkenal atau bersifat faktual.

Teks anekdot merupakan teks yang membahas mengenai hal lucu yang di dalamnya terdapat suatu pesan atau kritik yang ingin disampaikan secara tersirat. Kokasih (2014: 2) mengatakan bahwa anekdot adalah "teks yang berbentuk cerita, di dalamnya mengandung humor sekaligus kritik, karena mengandung kritik anekdot sering kali bersumber dari kisah-kisah faktua". Selain itu Chaer (2011: 158) mendefinisikan "anekdot merupakan sebuah teks yang berisi pengalaman seseorang yang tidak biasa, pengalaman yang tidak biasa tersebut disampaikan kepada orang lain dengan tujuan menghibur".

\section{c. Struktur Teks Anekdot}

Mahsun (dalam Buroman, 2020) menyatakan bahwa struktur dari teks anekdot yaitu: judul, pengenalan/orientasi, krisis/masalah, dan reaksi. Menurut Darmawati (2016:100), anekdot memiliki struktur yang membedakannya dengan jenis narasi lainnya. Struktur anekdot terbagi atas lima, yaitu abstrak, orientasi, krisis, reaksi, dan koda. Abstrak berada di paragraf awal anekdot. Hal tersebut sejalan dengan pemaparan Kosasih (2013:15) bahwa anekdot tidak semata-mata menyajikan hal-hal yang lucu, guyonan, ataupun humor akan tetapi terdapat pula tujuan lain di balik cerita atau teks anekdot memiliki struktur dan kaidahkaidah yaitu Struktur anekdot terdapat tokoh faktual yang biasanya orang-orang terkenal, latar yang bersifat faktual atau benar-benar ada dalam kehidupan nyata, dan alur yang merupakan rangkaian peristiwa yang benar-benar terjadi.

\section{d. Kaidah Kebahasaan Teks Anekdot}


Kaidah kebahasaan teks anekdot dapat juga disebut sebagai karakteristik atau ciri bahasa dari teks anekdot. Sebagaimana teks narasi lainnya, teks ini ditandai dengan pertama, menggunaan kalimat yang menyatakan peristiwa masa lalu. Kedua, menggunaan kalimat retoris (kalimat pertanyaan yang tidak membutuhkan jawaban. Ketiga, menggunakan konjungsi yang menyatakan hubungan waktu seperti kemudian, lalu. Keempat, menggunakan kata kerja aksi seperti menulis, membaca dan berjalan. Kelima, menggunakan kalimat perintah.

Kaidah-kaidah kebahasaan lain yang menandakan teks anekdot menurut Kemendikbud (2013: 112) sebagai berikut., sebagai berikut.

1) Menggunakan pertanyaan retorika, seperti: apakah kamu tahu?

2) Menggunakan kata sambung (konjungsi) waktu, seperti: kemudian, setelah itu, dan sebagainya.

3) Menggunakan kata kerja, seperti : pergi, tulis, dan sebagainya.

4) Menggunakan kalimat perintah.

Dalam teks anekdot terdapat ciri-ciri kebahasaan yang membedakan teks ini dengan teks-teks yang lain. Menurut Kemendikbud (2013:111), ciri kebahasaan dalam teks anekdot adalah. 1) Disajikan dalam bahasa lucu; Penyajian bahasa yang lucu adalah bahasa yang digunakan dalam penulisan teks anekdot dapat diplesetkan menjadi bahasa yang lucu. 2) Berisi peristiwa-peristiwa yang membuat jengkel. Maksud dari peristiwa yang membuat jengkel adalah cerita dalam teks anekdot itu dibuat konyol bagi partisipan yang mengalaminya. Mengenai ciri kebahasaan teks anekdot, pemilihan bahasa yang lucu sangat diperlukan. Dapat disimpulkan bahwa ciri kebahasaan dalam menulis teks anekdot adalah penyajian yang lucu dan berisi peristiwa-peristiwa yang membuat jengkel bagi pembacanya atau konyol tetapi di dalamnya ada trik yang membangun yang disampaikan oleh penulis kepada pembaca.

\section{e. Langkah-langkah Menulis Teks Anekdot}

Dalam menulis teks anekdot, hal-hal yang harus diperhatikan, yaitu menentukan topik dari teks anekdot yang akan dibuat, mencari bahan referensi sebelum menulis teks anekdot, menentukan pesan atau sindiran yang akan disampaikan, menentukan unsur lucu 
(konyol atau jengkel), menentukan alur cerita berdasarkan struktur teks anekdot, mengembangkan teks anekdot, menyunting teks, dan merevisi teks sesuai dengan hasil suntingan, serta member judul yang menarik pada teks anekdot yang telah dibuat.

\section{f. Indikator Penilaian Keterampilan Menulis Teks Anekdot}

Tes merupakan alat yang tepat untuk mengukur keterampilan menulis teks anekdot. Sudijono (2015: 65) menyebutkan bahwa tes adalah suatu kenyataan bahwa manusia dalam kehidupanya berbeda antara individu yang satu dengan individu lainya atau cara yang dapat di pergunakan atau prosedur yang perlu di tempuh dalam rangka pengukuran dan penilaian di bidang pendidikan. Disamping itu, Amir Daien (dalam Sudijono, 2007) mengatakan bahwa "Tes adalah suatu alat atau prosedur yang sistematis dan obyektif untuk memperoleh data-data atau keterangan yang diinginkan tentang seeseorang, dengan cara yang boleh dikatakan tepat dan cepat”. Dalam hal ini, tes mempunyai fungsi ganda yaitu untuk mengukur keberhasilan siswa dan program pengajaran.

Indikator yang digunakan dalam penilaian keterampilan menulis teks anekdot ada

lima macam. Pertama, ketepatan judul. Kedua, kelengkapan isi. Ketiga, keaktualan topik.. Keempat, kemenarikkan anekdot. Kelima,kepaduan cerita.

Sebelum melakukan penilaian tes keterampilan menulis teks ankedot, hal yang harus dilakukan adalah menentukan aspek-aspek yang akan dinilai. Aspek-aspek tersebut yaitu, struktur teks anekdot (abstrak, orientasi, krisis, reaksi, dan koda). Ciri bahasa atau kaidah kebahasaan teks anekdot (kalimat yang menyatakan peristiwa masa lalu, kalimat retoris, konjungsi, kata kerja aksi, dan kalimat perintah, serta kalimat seru), dan penerapan Ejaan Bahasa Indonesia (EBI) dalam menulis teks anekdot.

\section{1) Pengertian Huruf Kapital}

Menurut Afnita dan Iskandar (2019), dalam Ejaan Bahasa Indonesia (EBI), pemakaian huruf capital dipakai sebagai (1) huruf pertama awal kalimat, (2) huruf pertama unsur nama orang, termasuk julukan, (3) awal kalimat dalam petikan langsung, (4) huruf pertama setiap kata nma agama, kitab suci, dan Tuhan, termasuk sebutan dan kata ganti untuk Tuhan, (5) huruf pertama unsur 
nama gelar kehormatan, keturunan, keagamaan, atau akademik yang diikuti nama orang, termasuk gelar akademik yang mengikuti nama orang, (6) huruf pertama unsur jabatan dan pangkat yang diikuti nama orang atau yang dipakai sebagai pengganti nama orang tertentu, nama institusi, atau nama tempat, (7) huruf pertama nama bangsa, suku bangsa, dan bahasa, (8) huruf pertama nama tahun, bulan, dan hari besar atau hari raya, (9) huruf pertama nama geografi, (10) huruf pertama semua kata (termasuk semua unsur bentuk ulang sempurna) dalam nama negara, lembaga, badan, organisasi atau dokumen, kecali kata tugas, seperti di, ke, dari, dan, yang, dan untuk, (11) huruf pertama setiap kata (termasuk unsur kata ulang sempurna) di dalam judul buku, karangan, artikel, dan makalah, serta nama majalah dan surat kabar, kecuali kata tugas, seperti, di, ke, dari, dan, yang, dan untuk, yan tidak terletak pada posisi awal, (12) huruf pertama unsur singkatan nama, gelar, pangkat, atau sapaan, dan (13) huruf pertama kata penunjuk hubungan kekerabatan, seperti bapak, ibu, kakak, adik, dan paman, serta kata ungkapan lain yang dipakai dalam penyapaan atau pengacuan.

\section{2) Pengertian Tanda Titik}

Dalam Ejaan Bahasa Indonesia, pemakaian tanda titik ada lima macam, yaitu (1) tanda titik dipakai pada akhir kalimat pernyataan, (2) tanda titik dipakai di belakang angka atau huruf dalam suatu bagan, ikhtisar, atau daftar, (3) tanda titik dipakai untuk memisahkan angka, jam, menit, dan detik yang menunjukan waktu atau jangka waktu, (4) tanda titik dipakai dalam daftar pustaka di antara nama penulis, tahun, judul tulisan (yang tidak berakhir dengan tanda tanya atau tanda seru), dan tempat terbit, (5) tanda titik dipakai untuk memisahkan bilangan ribuan atau kelipatannya yang menunjukan jumlah.

\section{3) Pengertian Tanda Koma}

Dalam Ejaan Bahasa Indonesia, pemakaian tanda koma meliputi, (1) tanda koma dipakai di antara unsur-unsur dalam suatu pemerincian atau pembilangan, (2) tanda koma dipakai sebelum kata penghubung, (3) tanda koma dipakai untuk 
memisahkan anak kalimat yang mendahului induk kalimatnya, (4) tanda koma dipakai di belakang kata atau ungkapan penguhung antarkalimat, (5) tanda koma dipakai sebelum dan atau sesudah kata seru, (6) tanda koma dipakai untuk memisahkan petikan langsung dari lain dalam kalimat, (7) tanda koma dipakai di antara (a) nama dan alamat, (b) bagian-bagian alamat, (c) tempat dan tanggal, serta (d) nama tempat dan wilayah atau negeri yang ditulis berurutan, (8) tanda koma dipakai untuk memisah kan bagian nama yang di balik susunannya dalam daftar pustaka, (9) tanda koma dipakai di antara bagian-bagian dalam catatan kaki atau catatan akhir, (10) tanda koma dipakai di antara nama orang dan singkatan gelar akademis yang mengikutinya untuk membedakannya dari singkatan nama diri, keluarga, (11) tanda koma dipakai sebelum angka decimal atau di antara rupiah dan sen dinyatakan dengan angka, (12) tanda koma dipakai untuk mengapit keterangan tambahan atau keterangan aposisi, dan (13) tanda koma dipakai di belakang keterangan yang terdapat pada awal kalimat untuk menghindari salah baca atau salah pengertian.

\section{4) Pengertian Kata Depan}

Dalam Ejaan Bahasa Indonesia, pengunaan kata depan yaitu, (1) kata depan pada dan kepada, (2) kata depan oleh, (3) kata depan dengan, (4) kata depan atas, (5) kata depan antara, (6) kata depan di, ke, dan dari, ditulis terpisah dari kata yang mengikutinya.

Berdasarkan paparan di atas, dapat disimpulkan bahwa terdapat tiga indikator penilaian dalam keterampilan menulis teks anekdot. Pertama, dari segi struktur teks anekdot. Kedua, dari segi kaidah kebahasaan teks anekdot. Ketiga, dari segi Ejaan Bahasa Indonesia (EBI).

\section{Tabel 1}

\section{Indikator Penilaian Keterampilan Menulis Teks Anekdot \\ Siswa Kelas X SMK Negeri 3 Pariaman}

\begin{tabular}{|l|c|c|c|}
\hline No & Indikator Penilaian & & Deskripsi \\
\hline 1 & Struktur Teks Anekdot & a. Abstrak & \\
\hline
\end{tabular}




\begin{tabular}{|c|c|c|}
\hline & & $\begin{array}{l}\text { b. Orientasi } \\
\text { c. Krisis } \\
\text { d. Reaksi } \\
\text { e. Koda }\end{array}$ \\
\hline 2 & Kaidah Kebahasaan & $\begin{array}{l}\text { a. Menggunakan kalimat yang menyatakan } \\
\text { peristiwa masa lalu } \\
\text { b. Menggunakan kalimat retoris, konjungsi } \\
\text { c. Menggunakan kata kerja aksi } \\
\text { d. Menggunakan kalimat perintah } \\
\text { e. Menggunakan kalimat seru }\end{array}$ \\
\hline 3 & Ejaan Bahasa Indonesia & $\begin{array}{l}\text { a. Huruf capital } \\
\text { b. Tanda titik } \\
\text { c. Tanda Koma } \\
\text { d. Kata depan }\end{array}$ \\
\hline
\end{tabular}

Berdasarkan pemabahasan di atas, dapat disimpulkan bahwa menulis teks anekdot adalah sebuah kegiatan menulis cerita yang mengandung unsur humor dengan menampilkan tokoh tertentu yang bertujuan mengeritik dengan cara halus.

\section{Keterampilan Memahami Teks Anekdot}

\section{a. Pengertian Keterampilan Memahami Teks Anekdot}

Keterampilan memahami berhubungan dengan membaca pemahaman. Membaca pemahaman merupakan suatu kegiatan membaca yang bertujuan untuk memahami isi yang terkandung di dalam bacaan. Jika seseoang telah dapat memahami isi teks yang dibacanya, akan lebih mudah untuk menuangkan ide yang ada dalam pikirannya ke dalam bentuk tulisan.

Membaca bukan proses yang bersifat mekanis yang sederhana tetapi proses yang kompleks, hal ini karena kegiatan berpikir dan bernalar yang melibatkan kegiatan: mengenali, menginterpretasi, menilai, menalarkan bahkan memecahkan berbagai 
persoalan sehingga keterlibatan daya nalar menjadi sangat dominan (Priyatni dan Nurhadi, dalam Burohman, 2020). Sejalan dengan pendapat Tarigan (2015) membaca adalah suatu proses yang dilakukan serta dipergunakan oleh pembaca untuk memperoleh pesan yang hendak disampaikan oleh penulis melalui media kata-kata atau bahan tulis.

Membaca dalam arti sempit adalah kegiatan memahami makna yang terdapat dalam tulisan sedangkan dalam arti luas membaca adalah proses pengolahan bacaan secara kritis-kreatif yang dilakukan pembaca untuk memperoleh pemahaman menyeluruh tentang bacaan itu, yang diikuti oleh penilaian terhadap keadaan, nilai, fungsi, dan dampak bacaan itu (Nurhadi, 2016: 2).

Agustina (2008:15), membaca pemahaman adalah membaca yang dilakukan tanpa mengeluarkan bunyi atau suara. Membaca ini tidak menuntut pembacanya membunyikan atau mengoralkan bacaan, tetapi hanya menggunakan mata untuk melihat dan hati serta pikiran untuk memahaminya. Membaca pemahaman ini termasuk membaca intensif. Artinya, pembaca harus bersungguh-sungguh dalam menelaah isi bacaan serta berkonsentrasi terhadap apa yang dibacanya.

\section{b. Tujuan keterampilan Memahami Teks Anekdot}

Tujuan membaca pemahaman yang dikemukakan oleh Agustina (2008:15) yang mengatakan bahwa membaca pemahaman bertujuan untuk menangkap makna dari gagasan-gagasan yang terdapat dalam bacaan.

\section{c. Indikator Keterampilan Memahami Teks Anekdot}

Dalam penelitian ini diajukan empat indicator untuk menentukan keterampilan memahami teks anekdot. Pertama, siswa mampu menentukan struktur isi teks anekdot. Kedua, siswa mampu menentukan cirri-ciri bahasa teks anekdot. Ketiga, siswa mampu menentukan makna, kata, istilah, dan ungkapan dalam teks anekdot. Keempat, siswa mampu menyusun kembali t eks anekdot dengan memperhatikan makna, kata, istilah, dan ungkapan dalam teks anekdot.

\section{Tabel 2}

\section{Indikator Penilaian Keterampilan Memahami Teks Anekdot}




\section{Siswa Kelas X SMK Negeri 3 Pariaman}

\begin{tabular}{|c|c|c|}
\hline No & Indikator & Deskriptor \\
\hline 1 & 2 & 3 \\
\hline 1 & $\begin{array}{l}\text { Menentukan struktur isi teks } \\
\text { anekdot (abstrak, orientasi, } \\
\text { krisis, reaksi, dan koda). }\end{array}$ & $\begin{array}{l}\text { Disajikan teks anekdot, siswa diminta } \\
\text { menentukan struktur isi berdasarkan teks } \\
\text { tersebut. }\end{array}$ \\
\hline 1 & $\begin{array}{l}\text { Menentukan ciri-ciri bahasa } \\
\text { teks anekdot (pertanyaan retoris, } \\
\text { proses material, dan konjungsi } \\
\text { temporal) }\end{array}$ & $\begin{array}{l}\text { Disajikan teks anekdot, siswa diminta } \\
\text { menentukan cirri-ciri bahasa berdasarkan } \\
\text { teks tersebut. }\end{array}$ \\
\hline 2 & $\begin{array}{l}\text { Menentukan makna kata, istilah, } \\
\text { dan ungkapan dalam teks } \\
\text { anekdot }\end{array}$ & $\begin{array}{l}\text { Disajikan teks anekdot, siswa diminta } \\
\text { menentukan makna kata, istilah, dan } \\
\text { ungkapan berdasarkan teks tersebut. }\end{array}$ \\
\hline 3 & $\begin{array}{l}\text { Menyusun kembali teks anekdot } \\
\text { dengan memperhatikan makna } \\
\text { kata, istilah, dan ungkapan } \\
\text { dalam teks anekdot }\end{array}$ & $\begin{array}{l}\text { Disajikan teks anekdot, siswa diminta } \\
\text { menyusun teks anekdot dengan } \\
\text { memperhatikan makna kata, istilah, dan } \\
\text { ungkapan berdasarkan teks tersebut. }\end{array}$ \\
\hline
\end{tabular}

\section{Korelasi Keterampilan Memahami Teks Anekdot dengan Keterampilan Menulis Teks Anekdot}

Keterampilan berbahasa yang memerlukan tingkat penguasaan yang tinggi adalah keterampilan menulis. Pada umumnya menulis dianggap sebagai suatu keterampilan berbahasa yang sangat sulit dan dijadikan beban oleh siswa. Kesulitan ini disebabkan oleh faktor psikologis dan metodologis. Dalam keterampilan menulis juga dibutuhkan cara berpikir teratur yang menuntut latihan secara berkesinambungan dan terpola secara sistematis. Keterampilan menulis dapat mengarahkan siswa agar mampu menyampaikan ide dan gagasan untuk berbagai tujuan secara tertulis. Keterampilan menulis tidak akan datang secara otomatis, tetapi harus melalui praktik dan banyak berlatih dalam menulis. keterampilan menulis dibentuk dari beberapa keterampilan berbahasa (keterampilan menyimak, keterampilan berbicara, dan keterampilan membaca). 
Salah satu keterampilan yang harus dimiliki siswa sebagai langkah untuk meningkatkan keterampilan menulis teks anekdot adalah membaca pemahaman. Membaca pemahaman merupakan suatu kegiatan membaca yang bertujuan untuk memahami isi yang terkandung di dalam bacaan. Jika seseorang telah dapat memahami isi teks yang dibacanya, akan lebih mudah untuk menuangkan ide yang ada dalam pikirannya ke dalam bentuk tulisan. Dengan kata lain, Keberhasilan menulis dipengaruhi oleh pemahaman penulis terhadap pembaca tulisannya. Kemampuan ini memungkinkan kita sebagai penulis untuk memilih informasi serta cara penyajian yang sesuai. Dengan demikian, dapat ditarik suatu simpulan bahwa semakin banyak membaca dan berlatih dalam menulis, maka akan mudah siswa menulis teks anekdot sehingga menghasilkan tulisan yang berkualitas.

\section{B. Penelitian yang Relevan}

Penelitian yang relevan dengan penelitian ini di antaranya adalah sebagai berikut.

Pertama, penelitian dengan judul "Korelasi Keterampilan Memahami Teks Anekdot dengan Keterampilan Menulis Teks Anekdot Siswa Kelas X SMA Negeri 3 Padang Panjang” (Marisa, Arief, dan Nursaid, 2018). Pada penelitian ini diperoleh tiga kesimpulan. Pertama, Keterampilan menulis teks anekdot siswa kelas X SMA Negeri 3 Padang Panjang berada pada kualifikasi baik (B). Hal ini disebabkan karena siswa masih kurang mampu menuangkan gagasan, pikiran, dan jarangnya mendapatkan latihan untuk menulis saat proses belajar. Kedua, keterampilan memahami teks anekdot siswa kelas X SMA Negeri 3 Padang Panjang berada pada kualifikasi Baik Sekali (BS). Hal ini disebabkan, sebagian besar siswa sudah mulai mampu memahami struktur dan isi teks yang dibacanya. Siswa sudah memahami struktur teks yang dibacanya mulai dari abstrak, orientasi, krisis, reaksi, dan koda. Ketiga, terdapat hubungan yang berarti antara keterampilan memahami teks anekdot dengan keterampilan menulis teks anekdot siswa kelas X SMA Negeri 3 Padang Panjang pada tingkat kepercayaan 95\%.

Persamaan penelitian ini dengan penelitian yang dilakukan oleh Winda Marisa (2018) terletak pada jenis penelitiannya, yaitu penelitian kuantitatif dengan metode deskriptif, variabel bebas (X) yaitu keterampilan memahami teks anekdot, dan variabel terikat (Y) keterampilan menulis teks anekdot. Sedangkan perbedaannya terletak pada objek penelitian yaitu siswa kelas 
X SMK Negeri 3 Pariaman, sedangkan penelitian Winda Marisa (2018) objek penelitiannya adalah siswa kelas X SMA Negeri 3 Padang Panjang.

Kedua, penelitian dengan judul "Korelasi Keterampilan Membaca Pemahaman Teks Anekdot dengan Keterampilan Menulis Teks Anekdot Siswa Kelas X SMK Negeri 1 Lubuk Basung" (Izmi, Basri, dan Zulfikarni, 2018). Pada penelitian ini diperoleh tiga kesimpulan. Pertama, keterampilan membaca pemahaman teks anekdot siswa kelas X SMKN 1 Lubuk Basung berada pada kualifikasi baik karena rata-rata nilai keterampilan membaca pemahaman teks anekdot siswa secara umum, yaitu 78,69. Hal ini membuktikan bahwa keterampilan membaca pemahaman teks anekdot siswa kelas X SMKN 1 Lubuk Basung sudah memenuhi KKM karena nilai rata-rata mereka lebih besar daripada KKM yang telah ditetapkan (78,69 > 75,00). Kedua, keterampilan menulis teks anekdot siswa kelas X SMKN 1 Lubuk Basung berada pada kualifikasi baik karena rata-rata nilai keterampilan menulis teks anekdot siswa secara umum, yaitu 78,03. Hal ini membuktikan bahwa keterampilan menulis teks anekdot siswa kelas X SMKN 1 Lubuk Basung sudah memenuhi KKM karena nilai rata-rata mereka lebih besar daripada KKM yang telah ditetapkan $(78,03>75,00)$. Ketiga, terdapat korelasi yang signifikan antara keterampilan membaca pemahaman teks anekdot dengan keterampilan menulis teks anekdot siswa kelas X SMKN 1 Lubuk Basung pada derajat kebebasan $\mathrm{n}-1$ dan taraf signifikan 95\%. H0 ditolak dan H1 diterima karena hasil pengujian membuktikan bahwa nilai tabel lebih kecil daripada thitung.

Persamaan penelitian ini dengan penelitian yang dilakukan oleh Nur Izmi (2018) terletak pada jenis penelitiannya, yaitu penelitian kuantitatif dengan metode deskriptif, variabel bebas (X) yaitu keterampilan membaca pemahaman teks anekdot, dan variabel terikat (Y) keterampilan menulis teks anekdot. Sedangkan perbedaannya terletak pada objek penelitian yaitu siswa kelas X SMK Negeri 3 Pariaman, sedangkan penelitian Nur Izmi (2018) objek penelitiannya adalah siswa kelas X SMK Negeri 1 Lubuk Basung.

Ketiga, penelitian dengan judul "Korelasi antara Kebiasaan Membaca dengan Kemampuan Menulis Teks Anekdot pada Siswa Kelas X SMA Negeri 1 Talang Kelapa" (Burohman, Nurulanningsih, dan Milawasri, 2020). Pada penelitian ini diperoleh tiga kesimpulan. Pertama, hasil penelitian diperoleh hasil data dari kebiasaan membaca siswa kelas X SMA Negeri 1 Talang Kelapa diperoleh dengan instrumen penelitian berupa kuesioner 
(angket). Hasil yang didapat bahwa dari jumlah 32 siswa yang dipilih sebagai sampel penelitian terdapat 23 siswa (72\%) yang termasuk dalam kategori baik, Maka dapat disimpulkan bahwa tingkat kebiasaan membaca siswa kelas X SMA Negeri 1 Talang Kelapa termasuk dalam kategori baik. Kedua, Tingkat kemampuan menulis teks anekdot siswa kelas X SMA Negeri 1 Talang Kelapa dengan jumlah sampel 32 siswa diperoleh sebanyak 27 siswa (84\%) termasuk dalam kategori tuntas atau nilainya telah melewati Kriteria Ketuntasan Minimal (KKM). Jadi, dapat disimpulkan bahwa kemampuan menulis teks anekdot siswa kelas X SMA Negeri 1 Talang Kelapa termasuk dalam kategori sangat baik. Ketiga, terdapat Hubungan yang signifikan antara kebiasaan membaca dengan kemampuan menulis teks anekdot siswa kelas X SMA Negeri 1 Talang Kelapa. Penghitungan dilakukan dengan menggunakan rumus korelasi product moment yang didapat bahwa hasil rhitung $=0,474$ yang lebih besar dari hasil rtabel $=0,361$ dan dari hasil tersebut dapat dinyatakan bahwa adanya hubungan yang signifikan antara kebiasaan membaca dengan kemampuan menulis teks anekdot siswa kelas X SMA Negeri 1 Talang Kelapa dapat diterima.

Persamaan penelitian ini dengan penelitian yang dilakukan oleh Toni Habib Burohman (2020) terletak pada jenis penelitiannya, yaitu penelitian kuantitatif dengan metode deskriptif, variabel bebas $(\mathrm{X})$ yaitu kebiasaan membaca, dan variabel terikat (Y) kemampuan menulis teks anekdot. Sedangkan perbedaannya terletak pada objek penelitian yaitu siswa kelas X SMK Negeri 3 Pariaman, sedangkan penelitian Toni Habib Burohman (2020) objek penelitiannya adalah siswa kelas X SMA Negeri 1 Talang Kelapa.

\section{Kerangka Konseptual}

Secara konseptual terdapat korelasi antara variabel keterampilan memahami teks anekdot dan keterampilan menulis teks anekdot. Keterampilan memahami teks anekdot adalah variabel bebas (X), sedangkan keterampilan menulis teks anekdot adalah variabel terikat (Y). Untuk lebih jelasnya digambarkan dalam kerangka konseptual berikut.

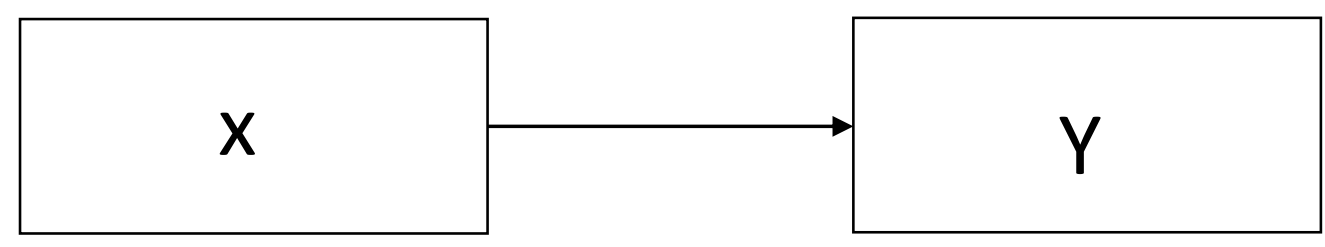




\title{
Gambar 2 Kerangka Konseptual
}

\author{
Keteranggan : \\ $\mathrm{X}=$ Keterampilan Memahami Teks Anekfot \\ $\mathrm{Y} \quad=$ Keterampilan Menulis Teks Anekdot \\ $\longrightarrow=$ Korelasi
}

\section{Hipotesis Penelitian}

Berdasarkan kajian teori dan kerangka konseptual yang telah dikemukakan sebelumnya, maka rumusan hipotesis penelitian ini adalah sebagai berikut.

H0 : Tidak terdapat korelasi yang signifikan antara keterampilan memahami teks anekdot dengan keterampilan menulis teks anekdot siswa kelas X SMK Negeri 3 Pariaman. Hipotesis diterima apabila $\mathrm{t}_{\text {hitung }}<\mathrm{t}_{\text {tabel }}$ dengan $\mathrm{dk}=\mathrm{n}-1$ pada tingkat signifikan 0,05 dan taraf kepercayaan $95 \%$.

H1 : Terdapat korelasi yang signifikan antara keterampilan memahami teks anekdot dengan keterampilan menulis teks anekdot siswa kelas X SMK Negeri 3 Pariaman.

Hipotesis diterima apabila $t_{\text {hitung }}>\mathrm{t}_{\text {tabel }}$ dengan $\mathrm{dk}=\mathrm{n}-1$ pada tingkat signifikan 0,05 dan taraf kepercayaan $95 \%$. 


\section{BAB III \\ METODOLOGI PENELITIAN}

\section{A. Jenis Penelitian}

Jenis penelitian ini adalah penelitian kuantitatif. Disebut kuantitatif karena informasi atau data yang diperoleh berupa numerik (angka) mulai dari pengumpulan data, penafsiran terhadap data, dan penampilan hasilnya (Arikunto, 2010).

Metode yang digunakan dalam penelitian ini adalah metode korelasional. Menurut Sukardi (2009: 166) penelitian korelasi adalah suatu penelitian yang melibatkan tindakan pengumpulan data guna menentukan, apakah ada hubungan dan tingkat hubungan antara dua variabel atau lebih.

Metode ini dilakukan dengan cara mengukur sejumlah variabel dan menghitung koefisien korelasi antara variabel-variabel tersebut, agar dapat ditentukan variabel-variabel mana yang berkorelasi. Kekuatan hubungan antar variabel penelitian ditunjukkan oleh koefisien korelasi yang angkanya bervariasi antara -1 sampai +1 . Koefisien korelasi adalah besaran yang diperoleh melalui perhitungan statistik berdasarkan kumpulan data hasil pengukuran setiap variabel. Koefisien korelasi positif menunjukkan hubungan yang berbanding lurus atau kesejajaran, sedangkan koefisien korelasi negatif menunjukkan hubungan berbanding terbalik atau ketidak-sejajaran. Rancangan (desain) penelitian korelasional ini digunakan untuk mengungkapkan hubungan antara dua variabel yaitu menganalisis hubungan keterampilan memahami teks anekdot dengan keterampilan menulis teks anekdot siswa kelas X SMK Negeri 3 Pariaman.

\section{B. Populasi dan Sampel}

Populasi dalam penelitian ini adalah siswa kelas X SMK Negeri 3 Pariaman yang terdaftar pada tahun 2020/2021. Jumlah siswa kelas X SMK pada semester ganjil 2020/2021 adalah sebnayak 168 orang yang tersebar di enam kelas. Sampel merupakan bagian populasi yang akan diteliti. Dikarenakan populasi penelitian lebih dari seratus siswa, maka perlu digunakan teknik pengambilan sampel. Pemilihan sampel penelitian ini dilakukan dengan teknik 
simple random sampling (teknik proporsional secara acak) dengan tujuan agar semua populasi dapat terwakili.

Subjek dalam penelitian ini berjumlah lebih dari 100. Hal ini mengisyaratkan bahwa jumlah subjek diambil antara 10-15\% atau 20-25\% atau lebih (Arikunto, 2010). Dalam b 1. penelitian ini, peneliti mengambil sampel sebanyak $25 \%$ dari jumlah populasi per kelas. Populasi dan sampel tersebut dapat dilihat pada tabel 4 berikut ini.

\section{Tabel 3}

\section{Populasi dan Sampel Penellitian}

\begin{tabular}{|c|c|c|c|}
\hline No & Kelas & Populasi & Sampel \\
\hline $\mathbf{1}$ & $\mathbf{2}$ & $\mathbf{3}$ & $\mathbf{4}$ \\
\hline 1 & X NKPI & 28 Orang & 7 Orang \\
\hline 2 & X TKPI & 28 Orang & 7 Orang \\
\hline 3 & X TKJ & 28 Orang & 7 Orang \\
\hline 4 & X RPL & 28 Orang & 7 Orang \\
\hline 5 & X TPTU & 28 Orang & 7 Orang \\
\hline 6 & X AGP & 28 Orang & 7 Orang \\
\hline \multicolumn{2}{|c|}{ Jumlah } & 168 Orang & 42 Orang \\
\hline
\end{tabular}

\section{Variabel dan Data}

Penelitian ini terdiri dari dua variabel, yaitu variabel bebas yang dilambangkan dengan huruf $\mathrm{X}$ dan variabel terikat yang dilambangkan dengan huruf Y. Variabel bebas (X) penelitian ini adalah keterampilan memahami teks anekdot siswa kelas X SMK Negeri 3 Pariaman. Variabel terikat (Y) pada penelitian ini adalah keterampilan menulis teks anekdot siswa kelas $\mathrm{X}$ SMK Negeri 3 Pariaman. Data penelitian ini adalah skor hasil tes keterampilan memahami teks anekdot dan skor hasil tes keterampilan menulis teks anekot siswa kelas X SMK Negeri 3 Pariaman.

\section{Instrumen Penelitian}


Instrumen yang digunakan dalam penelitian ini adalah berupa tes. Tes yang digunakan yakni tes objektif, dan tes unjuk kerja. Tes objektif digunakan untuk mengukur keterampilan memahami teks anekdot siswa dan tes unjuk kerja untuk mengukur keterampilan menulis teks anekdot siswa kelas X SMK Negeri 3 Pariaman. Berikut ini uraian mengenai tes objektif dan tes unjuk kerja.

\section{Tes Objektif}

Tes objektif digunakan untuk mengukur penguasaan kosakata bidang lingkungan dengan cara mengisi jawaban yang paling tepat dari alternatif yang tersedia. Dalam penelitian ini, tes objektif yang digunakan adalah tes pilihan ganda dengan empat pilihan jawaban (A, B, C, dan D). Sebelum dijadikan instrumen penelitian, terlebih dahulu dilakukan tes uji coba terhadap siswa lain di luar sampel yang telah ditentukan. Untuk lebih jelasnya kisi-kisi instrumen tersebut dapat dilihat pada tabel di bawah ini.

\section{Tabel 4}

Kisi-kisi Uji Coba Tes Keterampilan Memahami Teks Anekdot Siswa Kelas X SMK Negeri 3 Pariaman

\begin{tabular}{|c|l|c|}
\hline No & \multicolumn{1}{|c|}{ Indikator } & Jumlah Soal \\
\hline 1 & $\begin{array}{l}\text { Menentukan struktur isi teks anekdot (abstrak, orientasi, } \\
\text { krisis, reaksi, dan koda). }\end{array}$ & 16 \\
\hline 1 & $\begin{array}{l}\text { Menentukan ciri-ciri bahasa teks anekdot (pertanyaan retoris, } \\
\text { proses material, dan konjungsi temporal) }\end{array}$ & 17 \\
\hline 2 & $\begin{array}{l}\text { Menentukan makna kata, istilah, dan ungkapan dalam teks } \\
\text { anekdot }\end{array}$ & 10 \\
\hline 3 & $\begin{array}{l}\text { Menyusun kembali teks anekdot dengan memperhatikan } \\
\text { makna kata, istilah, dan ungkapan dalam teks anekdot }\end{array}$ & $\mathbf{6 0}$ \\
\hline Jumlah
\end{tabular}

Berdasarkan skor yang diperoleh pada tes uji coba tersebut, selanjutnya dianalisis validitas dan reliabilitasnya. Hal ini dilakukan agar tes yang digunakan dalam penelitian benar-benar dapat mengukur keterampilan siswa dan dapat dipertanggungjawabkan. 


\section{a. Validitas Item}

Valid berarti instrumen tersebut dapat digunakan untuk mendapatkan data itu valid. Validitas adalah derajat ketetapan suatu alat ukur tentang pokok isi atau arti sebenarnya yang diukur (Tuwu, 1993). Sejalan dengan pendapat Sujana dan Ibrahim (2009: 117) validitas berkenaan dengan kesanggupan instrumen mengukur isi yang harus diukur. Artinya, alat ukur tersebut mampu mengungkap isi suatu konsep atau variabel yang hendak diukur.

Jadi, validitas item dari suatu tes adalah ketepatan mengukur yang dimiliki sebutir item (yang merupakan bagian tak terpisahkan dari tes sebagai suatu totalitas), dalam mengukur apa yang seharusnya diukur lewat butir item tersebut.

Untuk menemukan validitas item dapat dilakukan dengan menggunakan rumus product memperson biserial berikut ini.

$$
r p b i=\frac{M_{p}-M_{t}}{S_{t}} \sqrt{\frac{p}{q}}
$$

Keterangan:

rpbi $=$ validitas item yang dicari

$\mathrm{M}_{\mathrm{P}}=$ rerata skor tester yang menjawab benar

$\mathrm{M}_{\mathrm{t}}=$ rerata skor total

$\mathrm{S}_{\mathrm{t}}=$ standar deviasi

$\mathrm{p}=$ rerata siswa yang menjawab benar

$\mathrm{q}=$ rerata siswa yang menjawab salah

(Arikunto, 2012)

Hasil dari penggunaan rumus biserial kemudian ditafsirkan ke dalam (rtabel) untuk mengetahui valid atau tidaknya item dengan taraf signifikan 95\% dan derajat kebebasan (dk) n-1. Jika hasil yang diperoleh rhitung lebih besar dari rtabel berarti soal tersebut dikatakan valid. Sebaliknya, jika hasil yang diperoleh rhitung lebih kecil dari rtabel, berarti soal tersebut dikatakan tidak valid. 
Validitas yang digunakan peneliti adalah validitas item, oleh karena itu masingmasing item/butir soal di uji dengan menggunakan product moment, jika butir soal/item valid maka layak untuk diteskan dan jika butir soal/item tidak valid maka tidak layak untuk diteskan.

\section{b. Reliabilitas Tes}

Reliabilitas adalah derajat ketepatan dan ketelitian atau akurasi yang ditunjukkan oleh instrumen pengukuran (Arikunto, 2006). Sebuah tes dikatakan dapat dipercaya jika tes tersebut diujikan berulang kali hasilnya relatif tetap atau kurang lebih sama. Reliabilitas tes dalam penelitian dapat ditentukan dengan teknik belah dua (split half method) jika diujikan satu kali dan jumlah item genap. Rumus yang digunakan adalah rumus product moment dan Spearman-Brown.

$$
r x y=\frac{n\left(\sum x y\right)-\left(\sum x\right)\left(\sum y\right)}{\sqrt{\left[n \sum x^{2}-\left(\sum x\right)^{2}\right] \cdot\left[n \sum y^{2}-\left(\sum y\right)^{2}\right]}}
$$

Keterangan :

rxy $=$ Koefisien korelasi antara variabel $\mathrm{X}$ dan $\mathrm{Y}$

$\mathrm{n} \quad=$ Banyaknya peserta tes

$\Sigma \mathrm{X}=$ Jumlah skor item

$\Sigma \mathrm{Y}=$ Jumlah skor total item

$\Sigma \mathrm{XY}=$ Hasil perkalian antara skor item dengan skor total

$\Sigma \mathrm{X} 2$ = Jumlah skor item kuadrat

$\Sigma Y 2$ = Jumlah skor total kuadrat

(Arikunto, 2006: 72)

Selanjutnya, hasil dari rumus product moment tersebut dimasukan ke dalam rumus Spearman-Brown berikut (Arikunto, 2012).

$$
r 11=2 r^{1 / 21 / 2}\left(1+r^{1 / 2} \frac{1 / 2}{}\right)
$$

Keterangan:

$r 11=$ koefisien reliabilitas yang sudah disesuaikan

$r^{1 / 2} 2^{1 / 2}=$ korelasi antara skor-skor setiap belahan tes 
Hasil dari penggunaan rumus Spearman-Brown ditafsirkan ke dalam rtabel untuk mengetahui reliabel atau tidaknya tes tersebut dengan taraf signifikansi $95 \%$ dan derajat kebebasan (dk) n-1. Jika hasil yang yang diperoleh (rhitung) lebih besar 32 dari rtabel, berarti soal tersebut dikatakan reliabel. Sebaliknya, jika hasil yang diperoleh (rhitung) lebih kecil dari rtabel, berarti soal tersebut dikatakan tidak reliabel.

\section{Tes Unjuk Kerja}

Tes unjuk kerja digunakan untuk mengumpulkan data keterampilan menulis teks anekdot siswa kelas X SMK Negeri 3 Pariaman. Melalui tes tersebut siswa diminta untuk menulis teks anekdot berdasarkan topik yang disediakan. Keabsahan instrumen menulis teks anekdot dipertimbangkan melalui indikator tes yang digunakan untuk keterampilan teks anekdot, yaitu (1) siswa mampu menulis sesuai dengan struktur teks anekdot, (2) siswa mampu menulis teks anekdot sesuai dengan kaidah kebahasaan, dan (3) siswa mampu menerapkan EBI secara tepat.

Untuk pengumpulan data keterampilan menulis teks anekdot, siswa ditugaskan menulis sebuah teks anekdot dengan tema yang yang telah ditentukan. Siswa dituntut untuk mampu memproduksi teks anekdot sesuai dengan struktur dan kaidah kebahasaan, sebagaimana yang telah dijelaskan pada bagian indikator keterampilan menulis teks anekdot.

\section{E. Teknik Pengumpulan Data}

Teknik pengumpulan data dalam penelitian ini dilakukan dengan dua cara sebagai berikut. Pertama, siswa diminta untuk mengerjakan tes objektif (pilihan ganda) berhubungan dengan keterampilan memahami teks anekdot yang berjumlah 41 butir soal dilengkapi dengan lembar jawaban. Sesuai petunjuk soal, siswa diminta menyilang salah satu huruf A, B, C, atau D pada lembar jawaban. Lembar jawaban kemudian dikumpulkan kembali untuk selanjutnya diolah berdasarkan teknik analisis data.

Kedua, memberikan tes unjuk kerja untuk mengukur keterampilan menulis teks anekdot siswa. Siswa diminta untuk menuliskan teks anekdot dengan memperhatikan indikator menulis teks anekdot. Setelah selesai mengerjakan tes, tulisan siswa dikumpulkan dan dilakukan analisis sesuai dengan indikator penilaian tes unjuk kerja. 


\section{F. Uji Persyaratan Analisis Data}

Uji persyaratan analisis yang dilakukan dalam penelitian ini adalah uji normalitas. Uji normalitas bertujuan untuk mengetahui apakah data berdistribusi normal atau sebaliknya. Uji normalitas data menjadi syarat untuk menentukan jenis statistik yang akan dipakai dalam penganalisisan data nantinya. Dalam penelitian ini, pengujian apakah data berdistribusi normal atau tidak, yaitu dengan menggunakan uji liliefors, dengan langkah-langkah berikut ini.

1. Menyusun data $\mathrm{X} 1, \mathrm{X} 2, \mathrm{X} 3, \ldots, \mathrm{Xn}$ yang diurutkan dari data terkecil hingga data yang terbesar.

2. Data $\mathrm{X} 1, \mathrm{X} 2, \mathrm{X} 3, \ldots, \mathrm{Xn}$ dijadikan bilangan baku $\mathrm{Z1}, \mathrm{Z2}, \mathrm{Z3}, \ldots, \mathrm{Zn}$ dengan rumus

$$
Z i=x i-\bar{x} s
$$

$$
\begin{aligned}
& \text { Keterangan: } \\
& x i=\text { skor yang diperoleh siswa } \\
& x=\text { skor rata-rata } \\
& s=\text { standar deviasi }
\end{aligned}
$$

3. Dengan menggunakan daftar distribusi baku, kemudian dihitung peluang $\mathrm{F}(\mathrm{zi})=\mathrm{P}(\mathrm{z} \leq \mathrm{zi})$

4. Selanjutnya, dihitung proporsi $z 1, z 2, z 3, \ldots z n$ yang lebih kecil atau sama dengan zi. Jika proporsi ini dinyatakan dengan $\mathrm{S}(\mathrm{zi})$, maka:

$$
S(z i)=\text { banyaknya } z 1, z 2, z 3, \ldots, z n \text { yang } \leq \mathrm{zi} \mathrm{n}
$$

5. Menghitung selisih F(zi)-S(zi), kemudian menentukan harga mutlaknya.

6. Ambil nilai harga yang paling besar di antara harga-harga mutlak selisih, disebut $\mathrm{L}_{0}$.

7. Membandingkan nilai $L 0$ dengan nilai kritis $L_{t}$ yang terdapat pada taraf signifikansi 0,05 . Kriterianya yaitu populasi dinyatakan berdistribusi normal jika $\mathrm{L}_{0}$ hitung)

\section{G. Teknik Penganalisisan Data}

Setelah data terkumpul, teknik selanjutnya adalah menganalisis data penelitian yang dilakukan berdasarkan tahap-tahap sebagai berikut. Pertama, memberikan skor terhadap tes anekdot. Penskoran bersifat mutlak, skor 1 untuk jawaban yang benar dan skor 0 untuk jawaban yang salah. 
Kedua, penentuan skor keterampilan menulis teks anekdot dengan tes yang dinilai, yaitu struktur, kaidah kebahasaan, dan penerapan Ejaan Bahasa Indonesia (EBI) yang dilakukan berdasarkan tabel 5 .

\section{Tabel 5}

Rubrik Penilain Keterampilan Menulis Teks Anekdot

Siswa Kelas X SMK Negeri 3 Pariaman

\begin{tabular}{|c|c|c|c|c|c|}
\hline \multirow[t]{2}{*}{ No } & \multirow{2}{*}{$\begin{array}{l}\text { Indikator } \\
\text { Penilaian }\end{array}$} & \multirow[t]{2}{*}{ Sub Aspek } & \multicolumn{3}{|c|}{ Skor } \\
\hline & & & 1 & 2 & 3 \\
\hline 1 & 2 & 3 & 4 & 5 & 6 \\
\hline 1 & $\begin{array}{c}\text { Struktur } \\
\text { Teks } \\
\text { Anekdot }\end{array}$ & $\begin{array}{l}\text { a. Abstrak } \\
\text { b. Orientasi } \\
\text { c. Krisis } \\
\text { d. Reaksi } \\
\text { e. Koda }\end{array}$ & $\begin{array}{l}\text { Apabila siswa } \\
\text { menuliskan } \\
\text { secara lengkap } \\
\text { kelima struktur } \\
\text { (abstrak, } \\
\text { orientasi, } \\
\text { krisis, reaksi, } \\
\text { dan koda) } \\
\text { dan lengkap. }\end{array}$ & $\begin{array}{l}\text { Apabila siswa } \\
\text { menuliskan } \\
\text { secara lengkap } \\
\text { kelima struktur } \\
\text { (abstrak, } \\
\text { orientasi, krisis, } \\
\text { reaksi, dan } \\
\text { koda) tetapi } \\
\text { tidak lengkap. }\end{array}$ & $\begin{array}{l}\text { Apabila siswa } \\
\text { menuliskan } \\
\text { lengkap secara } \\
\text { struktur } \quad \text { kelima } \\
\text { orientasi, krisis, } \\
\text { reaksi, dan koda) } \\
\text { kurang lengkap. }\end{array}$ \\
\hline 2 & $\begin{array}{c}\text { Kaidah } \\
\text { Kebahasaan }\end{array}$ & \begin{tabular}{|ll} 
a. & Menggunaka \\
& $\mathrm{n} \quad$ kalimat \\
& yang \\
& menyatakan \\
& peristiwa \\
& masa lalu. \\
b. & Menggunaka \\
& n pertanyaan \\
& retorika. \\
c. & Menggunaka \\
& $\mathrm{n} \quad$ kata
\end{tabular} & $\begin{array}{l}\text { Apabila teks } \\
\text { anekdot yang } \\
\text { ditulis } \\
\text { mengacu pada } \\
\text { satu/dua aspek } \\
\text { dan mengacu } \\
\text { pada tema } \\
\text { yang } \\
\text { ditentukan. }\end{array}$ & $\begin{array}{l}\text { Apabila teks } \\
\text { anekdot yang } \\
\text { ditulis mengacu } \\
\text { pada tiga/empat } \\
\text { aspek dan } \\
\text { mengacu pada } \\
\text { tema yang } \\
\text { ditentukan. }\end{array}$ & $\begin{array}{lr}\text { Apabila } & \text { teks } \\
\text { anekdot } & \text { yang } \\
\text { ditulis } & \text { mengacu } \\
\text { pada } & \text { lima/enam } \\
\text { aspek dan mengacu } \\
\text { pada tema yang } \\
\text { ditentukan. }\end{array}$ \\
\hline
\end{tabular}




\begin{tabular}{|c|c|c|c|c|c|}
\hline & & $\begin{array}{ll} & \text { sambung } \\
& \text { (konjungsi). } \\
\text { d. } & \text { Menggunaka } \\
& \text { n kata kerj } \\
& \text { aksi. } \\
\text { e. } & \text { Menggunaka } \\
& \text { n kalima } \\
& \text { perintah. } \\
\text { f. } & \text { Menggunaka } \\
& \text { n kalima } \\
& \text { seru. }\end{array}$ & & & \\
\hline 3 & EBI & $\begin{array}{l}\text { a. Huruf } \\
\text { Kapital } \\
\text { b. Tanda titik } \\
\text { c. Tanda koma. } \\
\text { d. Kata depan. }\end{array}$ & $\begin{array}{l}\text { Apabila } \\
\text { jumlah } \\
\text { kesalahan } \\
\text { ejaan lebih dari } \\
75 \%\end{array}$ & $\begin{array}{l}\text { Apabila jumlah } \\
\text { kesalahan ejaan } \\
\text { antara } 51 \%-75 \%\end{array}$ & $\begin{array}{l}\text { Apabila jumlah } \\
\text { kesalahan } \\
\text { kurang dari } 50 \%\end{array}$ \\
\hline
\end{tabular}

Ketiga, mengubah skor menjadi nilai. Untuk menghitung nilai yang diperoleh siswa dilakukan berdasarkan rumus persentase berikut.

$$
\mathrm{N}=S M S I \times S M a x
$$

Keterangan:

$\mathrm{N}=$ tingkat penguasaan

$\mathrm{SM}=$ skor yang diperoleh

SI $=$ skor yang harus dicapai dalam suatu tes

$\mathrm{S}$ Max = skala yang digunakan

(Abdurahman \& Ratna, 2003)

Keempat, mengklasifikasikan nilai keterampilan memahami teks anekdot dan keterampilan menulis teks anekdot berdasarkan rata-rata hitung dan Kriteria Ketuntasan Minimal (KKM) dengan menggunakan skala 10 pada tabel 6. 
Tabel 6

Pedoman Konversi Nilai Siswa dengan Skala 10

\begin{tabular}{|c|c|c|c|}
\hline No. & Tingkat Pemahaman & Nilai Ubahan Skor & Kualifikasi \\
\hline 1 & $96 \%-100 \%$ & 10 & Sempurna \\
\hline 2 & $86 \%-95 \%$ & 9 & Baik Sekali \\
\hline 3 & $76 \%-85 \%$ & 8 & Baik \\
\hline 4 & $66 \%-75 \%$ & 7 & Lebih dari Cukup \\
\hline 5 & $56 \%-65 \%$ & 6 & Cukup \\
\hline 6 & $46 \%-55 \%$ & 5 & Hampir Cukup \\
\hline 7 & $36 \%-45 \%$ & 4 & Kurang Sekali \\
\hline 8 & $26 \%-35 \%$ & 3 & Buruk \\
\hline 9 & $16 \%-25 \%$ & 2 & Buruk Sekali \\
\hline 10 & $0 \%-15 \%$ & 1 & \\
\hline
\end{tabular}

Nurgiyantoro (Abdurahman \& Ratna, 2003)

Kelima, menafsirkan nilai penguasaan kosakata dan keterampilan menulis teks anekdot siswa kelas X SMK Negeri 3 Pariaman secara umum dan per indikator berdasarkan nilai ratarata hitung (M). Rumus yang dipergunakan untuk menilai rata-rata hitung adalah sebagai berikut.

$$
M=\frac{\sum F X}{N}
$$

Keterangan:

$\mathrm{M}=$ mean (rata-rata hitung)

$\Sigma F X=$ jumlah nilai keseluruhan

$\mathrm{N}=$ jumlah sampel

Keenam, membuat diagram batang keterampilan memahami teks anekdot dan keterampilan menulis teks anekdot secara umum dan per indikator. 
Ketujuh, mengkorelasikan nilai keterampilan memahami teks anekdot dengan keterampilan menulis teks anekdot menggunakan rumus product moment berikut.

$$
r x y=\frac{n\left(\sum x y\right)-\left(\sum x\right)\left(\sum y\right)}{\sqrt{\left[n \sum x^{2}-\left(\sum x\right)^{2}\right] \cdot\left[n \sum y^{2}-\left(\sum y\right)^{2}\right]}}
$$

Keterangan :

rxy $\quad=$ Koefisien korelasi antara variabel $\mathrm{X}$ dan $\mathrm{Y}$

$\mathrm{n} \quad=$ Banyaknya peserta tes

$\Sigma \mathrm{X}=$ Jumlah skor item

$\Sigma \mathrm{Y} \quad=$ Jumlah skor total item

$\Sigma \mathrm{XY}=$ Hasil perkalian antara skor item dengan skor total

$\Sigma \mathrm{X} 2$ = Jumlah skor item kuadrat

$\Sigma Y 2$ = Jumlah skor total kuadrat

Kedelapan, menguji kebeartian hipotesis yang diajukan. Kebeartian hipotesis ditentukan dengan rumus berikut ini.

$$
t=r \frac{\sqrt{n-2}}{\sqrt{1-r^{2}}}
$$

\section{Keterangan:}

$\mathrm{t}=$ besaran pengujian hipotesis/signifikan/kebeartian

$\mathrm{r}=$ koefisien korelasi

$\mathrm{n}=$ jumlah sampel

Kesembilan, membuat kesimpulan tentang hasil penelitian dan menyimpulkan hasil pembahasan dengan cara mendeskripsikan korelasi antara keterampilan memahami teks anekdot dengan keterampilan menulis teks anekdot siswa kelas X SMK Negeri 3 Pariaman. 


\section{DAFTAR PUSTAKA}

Abdurrahman dan Ellya Ratna. (2003). Evaluasi Pembelajaran Bahasa dan Sastra Indonesia (Buku Ajar) (pp. 36, 264-265). Padang: FBS UNP.

Afnita dan Zelvi Iksandar. (2019). Bahasa Indonesia untuk Perguruan Tinggi. Jakarta: Kencana. Agustina. 2008. "Pembelajaran Keterampilan Membaca”. Buku Ajar. Padang: Jurusan Bahasa dan Sastra Indonesia FBS UNP.

Aieny, Melani Putri. (2019). "Korelasi Keterampilan Membaca Pemahaman Teks Eksposisi dengan Keterampilan Menulis Teks Eksposisi Siswa Kelas VIII SMP Negeri 34 Padang”. Jurnal Pendidikan Bahasa dan Sastra Indonesia, Vol. IX, No.I, (Online), (http://ejournal.unp.ac.id/index.php/pbs/article/view/108273/103294, diakses 10 Oktober 2021).

Anderson dan Krathwohl. (2010). Kerangka Landasan untuk Pembelajaran, Pengajaran, dan Asesmen. Yogyakarta: Pustaka Pelajar.

Apriyenti, L., Aurora, N., \& Afnita, A. (2019). Korelasi Keterampilan Membaca Pemahaman

Dan Keterampilan Menulis Teks Hasil Observasi Siswa Kelas VII SMPN 16 Tebo. Caraka, 5(2), 141. https://doi.org/10.30738/caraka.v5i2.4400.

Arikunto, Suharsimi. (2006). Prosedur Penelitian Suatu Pendekatan dan Praktik Edisi Revisi VI. Jakarta: Rineka Cipta.

Arikunto, Suharsimi. (2012). Dasar-dasar Evaluasi Pendidikan. Jakarta: Bumi Aksara.

Burohman, Toni, dkk. (2020). "Korelasi Antara Kebiasaan Membaca dengan Kemampuan Menulis Teks Anekdot pada Ssiwa Kelas X SMA Negeri 1 Talang Kelapa”. Jurnal Didactique Bahasa Indonesia, Vol. I, No. I, (Online), (http://univtridinanti.ac.id/ejournal/index.php/didactiquebahasa/article/download/603/588, diakses 4 November 2021).

Chaer, Abdul. (2011). Tata Bahasa Praktis Bahasa Indonesia. Jakarta: Rineka Cipta.

Cole, J., \& Feng, J. (2015). Chinese American Educational Research and Development Association Annual Conference. Effective Strategies for Improving Writing Skills of Elementary English Language Learners, 1-25.

Dalman. 2012. Menulis Karya Ilmiah. Jakarta: PT Raja Grafindo Persada. 
Dalman, H. (2016). Keterampilan Menulis. Jakarta: PT Raja Grafindo Persada.

Darmawati, Uti dan Budi Artati. (2016). Bahasa Indonesia Kelas X Wajib. (Buku Siswa). Klaten: Intan pariawara.

Frecelya, Adryani Fyola. (2019). "Korelasi Penguasaan Kosa Kata dengan Keterampilan

Menulis Teks Eksposisi Siswa Kelas X SMK Negeri 2 Padang”. Jurnal Pendidikan Bahasa dan Sastra Indonesia, Vol. VIII, No. IV, (Online), (http://ejournal.unp.ac.id/index.php/pbs/article/view/106904, diakses 19 September 2021).

Gani, E. (1999). Pembinaan Keterampilan Menulis di Perguruan Tinggi. Buku Ajar. Padang: Fakultas Bahasa dan Seni UNP.

Ghazali, Syukur. (2013). Pembelajaran Keterampilan Berbahasa Dengan Pendidikan Komunikatif-nteraktif. Bandung: PT Refik.

Ghazali, Akbar Maulana. (2020). "Korelasi Keterampilan Membaca Pemahaman dengan Keterampilan Menulis Teks Berita Siswa Kelas VII SMP Negeri 9 Padang”. Jurnal Pendidikan Bahasa dan Sastra Indonesia, Vol. IX, No. I, (Online), (http://ejournal.unp.ac.id/index.php/pbs/article/view/108258, diakses 19 September 2021).

Geiser, S., \& Studley, R. E. (2010). UC and the SAT. Rethinking the SAT, 125-154.

Graham, S., dan Perin, D. (2007). Writing next: Effective strategies to improve writing of adolescents in middleand high schools-A report to Carnegie Corporation of New York. Washington, DC: Alliance for Excellent Education.

Izmi, Nur, dkk. (2018). "Korelasi Keterampilan Membaca Pemahaman Teks Anekdot dengan Keterampilan Menulis Teks Anekdot Siswa Kelas X SMK Negeri 1 Lubuk Basung”. Jurnal Pendidikan Bahasa dan Sastra Indonesia, Vol. VII, No. IV, (Online), (http://ejournal.unp.ac.id/index.php/pbs/article/view/102335, diakses 2 November 2021).

Kemendikbud. (2013). Buku Siswa Bhasa Indonesia X Expresi Diri dan Akademik. Jakarta:

Kemendikbud.

Kokasih, E. (2013). Kreatif Berbahasa Indonesia. Jakarta: Erlangga.

Kokasih, E. (2014). Jenis-jenis Teks dalam Mata Pelajaran Bahasa Indonesia Kurikulum 2013. Jakarta: Rajawali Pers.

Mangen, A., Walgermo, B.R., dan Bronnick, K. (2013). Reading Linear Texts on Paper Versus 
Computer Screen: Effects on Reading Comprehension. International of Education Research. 58, 61-68.

Marisa, Winda. (2018). “Korelasi Keterampilan Memahami Teks Anekdot dengan Keteranpilan Menulis Teks Anekdot Siswa Kelas X SMA Negeri 3 Padang Panjang”. Jurnal Pendidikan Bahasa dan Sastra Indonesia, Vol. VII, No.III, (Online), (http://ejournal.unp.ac.id/index.php/pbs/article/view/100766, diakses 2 November 2021. Maryanto, dkk. (2014). Bahasa Indonesia Ekspresi Diri dan Akademik. Jakarta: Kementrian Pendidikan dan Kebudayaan.

Nurhadi. (2016). Teknik Membaca. Jakarta: Bumi Aksara.

Pateda, Mansoer. (1989). Analisis Kesalahan. NTT : Nusa Indah.

Rahmawita, Sari. (2019). “Kontribusi Keterampilan Membaca Teks Fabel terhadap Keterampilan Menulis Teks Fabel Ssiwa Kelas VII SMP Negeri 25 Padang”. Jurnal Pendidikan Bahasa dan Sastra Indonesia, Vol. VIII, No.III, (Online), (http://ejournal.unp.ac.id/index.php/pbs/article/view/108225, diakses 19 September 2021).

Safa, A. J. (2018). A Brief Overview of Key Issues in Second Language Writing Teaching and Research. International Journal of Education \& Literacy Studies, 6(2), 15-25.

Sagala S. (2011). Konsep dan Makna Pembelajaran. Bandung: Alfabeta.

Sari, Titis Antika. (2017). "Keefektifan Pembelajaran Memproduksi Teks Anekdot dengan Model Sinektiks dan Problem Based Instruction pada Siswa Kelas X SMA Bergaya Kognitif Field Dependen dan Field Independent”. Jurnal Pendidikan Bahasa dan Sastra, Vol. VI, No. I, hlm 34-39, (Online), (http://journal.unnes.ac.id/sju/index.php/jpbsi, diakses pada 17 September 2021).

Sayed, O. H. (2010). Developing Business Management Students' Persuasive Writing Through Blog-based Peer-Feedback. English Language Teaching, 3(3), 54-66.

Semi, M. Atar. (2007). Dasar-dasar Keterampilan Menulis. Bandung: Angkasa.

Sudijono, Anas. (2007). Pengantara Evaluasi Pendidikan. Jakarta: PT Raja Grafindo Persada. Sudijono, Anas. (2015). Pengantar Evaluasi Pendidikan. Jakarta: PT Raja. Grafindo Persada. Sujana, Nana dan Ibrahim. (2009). Penelitian dan Penilaian Pendidikan. Bandung: Sinar Baru Algendindo. 
Sukardi. (2006). Penelitian Kualitatif-Naturalistik dalam Pendidikan. Yogyakarta: Usaha Keluarga.

Supriadin. (2016). "Peningkatan Hasil Belajar Menulis Kalimat Efektif dalam Paragraf Argumentasi Melalu Kegiatan Peer Corection pada Siswa Kelas VIII SMPN1 Ambalawi Kabupaten Bima Tahun Pelajaran 2014/2015.” Jurnal Ilmiah Mandala Education Vol.2 No 1, (Online), (http://ejournal.mandalanursa.org/index.php/JIME/article/view/99/96, diakses 19 September 2021).

Tarigan, Henry Guntur. (1994). Membaca Sebagai Sutau Keterampilan Berbahasa. Bandung: Angkassa.

Tarigan, Henry Guntur. (2009). Menulis sebagai Suatu Keterampilan Berbahasa. Bandung: Angkasa.

Tarigan, Henry Guntur. (2015). Membaca: Sebagai Suatu Keterampilan Berbahassa. Bandung: Angkasa.

Tuwu, Alaudin. (1993). Pengantar Metode Penelitian. Jakarta: Universitas IndonesiaI Press.

Wardani, dkk. (2017). "Studi Kasus Pembelajaran Menulis Teks Anekdot pada Kurikulum 2013 di SMA Negeri 1 Surakarta”. Aksara, Vol. II, No.I, (Online), (https://aksara.online/article/view/17361/11596, diakses 19 September 2021).

Widia, Wina. (2020). “ Korelasi Penguasaan Kosakata Bidang Lingkungan Hidup dan Keterampilan Menulis Teks Eksplanasi Ssiwa Kelas XI SMK Negeri 2 Padang”. Jurnal Pendidikan Bahasa dan Sastra Indonesia, Vol. IX, No. 1, (Online), (http://ejournal.unp.ac.id/index.php/pbs/article/view/108282/103302, diakses 29 Oktober 2021). 